\title{
EVALUASI PROGRAM PEMBINAAN TIM BOLAVOLI PUTERI SUMATERA SELATAN
}

\author{
M. Fransazeli Makorohim \\ Universitas Islam Riau \\ mfransazeli@edu.uir.ac.id
}

\begin{abstract}
ABSTRAK
Penelitian ini bertujuan 1) mendeskripsikan program pembinaan tim bola voli puteri Sumatera Selatan, 2) mendeskripsikan penerimaan atlet, pelatih, asisten, kelayakan sarana prasarana, pembiayaan pelaksanaan program pembinaan, 3) mendeskripsikan pelaksanaan program latihan, konsumsi, koordinasi, kesejahteraan, transportasi, 4) mendeskripsikan keberhasilan pembinaan tim bola voli puteri Sumatera Selatan. Penelitian ini adalah penelitian evaluasi dengan metode CIPP. Populasi penelitian ini tim bola voli puteri Sumatera Selatan. Teknik pengumpulan data dengan observasi, wawancara, dokumentasi, dan triangulasi data. Data yang diperoleh dianalisis secara kualitatif dengan 1) reduksi data, 2) penyajian data, 3) penarikan kesimpulan. Penelitian ini menghasilkan: 1) Program pembinaan tidak berjalan dengan baik, 2) Sarana prasarana kurang memadai dan dana pembinaan dari anggaran KONI dan pihak ketiga, 3) tidak ada penyeleksian penerimaan pelatih dan asisten, tidak ada kompetisi menyeleksi atlet, program latihan cukup baik, 4) kurang perhatian pemerintah terhadap perkembangan prestasi olahraga beregu, 5) tidak ada pembinaan prestasi dari PBVSI, 6) Atlet belum berprestasi dinasional. Penelitian ini menyimpulkan: 1) context Pembinaan prestasi yang tidak jelas dari PBVSI, 2) Input Penyeleksian atlet, pelatih, asisten pelatih dan pendanaan masih kurang, 3) Process program latihan cukup baik, kesehjateraan atlet, pelatih dan asisten belum terjamin dan tidak ada transportasi atlet, 4) Product Pembinaan PBVSI belum berhasil.
\end{abstract}

Kata Kunci: Bolavoli, Evaluasi Program, Pembinaan

\section{PENDAHULUAN}

Pembinaan olahraga perlu dilakukan secara terus menerus, berjenjang, berkelanjutan dan berkesinambungan melalui proses panjang untuk dapat diperoleh atlet yang handal. Oleh karena itu, pencapaian prestasi puncak perlu dijabarkan dalam suatu konsep yang menyeluruh dalam suatu pola pembinaan yang berjenjang. Dalam hal ini, untuk pencapaian prestasi puncak olahraga nasional ditempuh melalui suatu pola pembinaan olahraga nasional yang mengacu pada sistem piramida. Sistem piramida yang dimaksud mencakup pemasalan, pembibitan, pembinaan prestasi untuk mencapai prestasi puncak (Dirjen Olahraga dan Depdiknas, 2004:1).

Harsono (2000:65) menyatakan bahwa salah satu strategi yang paling mendasar dalam upaya mewujudkan sumber daya manusia Indonesia khususnya di bidang olahraga adalah dengan memusatkan perhatian dan orientasi pembangunan olahraga sedini mungkin yakni dengan melakukan pembinaan dan pengembangan olahraga bagi generasi muda sejak dini.

Persoalan utama dalam sistem pembinaan olahraga disebabkan karena kurang seriusnya pembinaan olahraga itu sendiri. Pola pengembangan olahraga nasional masih 
bersifat tradisional, tak lebih dari rutinitas sebagai bagian ritual yang berorientasi pada pencapaian prestasi secara instan berdasarkan pengalaman masa lalu yang miskin inovasi. Berpijak dari fakta tersebut, upaya untuk mengembalikan kejayaan olahraga nasional, tidak bisa tidak, harus dimulai melalui reformasi bangunan sistem keolahragaan dengan penekanan utama pada pergeseran paradigma pembinaan olahraga yang tidak sekadar berorientasi pada pencapaian medali. Medali harus dianggap sebagai konsekuensi logis pembinaan olahraga yang tertata dan terintegrasi dalam sistem yang mapan. Walaupun kualitas dan kuanititas piala atau medali, yang diperoleh dalam sebuah kejuaraan adalah indikator kemajuan olahraga dan indikator karakter atau mentalitas bangsa dari negara tersebut.

Ada tiga tantangan pembangunan olahraga sekarang ini dan kedepan, yaitu: (1) tingginya tuntutan publik terhadap prestasi olahraga agar maju sama dengan prestasi negara lain, daerah lain, kelompok atau orang lain (kompetensi dan hasil prestasi), (2) menjadikan olahraga sebagai instrumen pembangunan, dan (3) desentralisasi pembangunan olahraga (http://artikel-olahraga.blogspot.com,2008).

Inti dari desentralisasi pembangunan olahraga adalah pemberdayaan masyarakat, perubahan prakarsa dan kreativitas. Desentralisasi di negara Indonesia ada pada daerah Kabupaten/Kota, ibaratnya bola ada di Pemerintah Kabupaten/Kota. Lalu bagaimana model pembangunan olahraga era otonomi daerah. Secara konsepsial, telah dirancang pola pembinaan atlet secara berjenjang mulai dari anak-anak usia dini setingkat sekolah dasar, dibina, diseleksi untuk mengikuti kompetisi sampai tingkat nasional. Demikian juga anak-anak usia tingkat SLTP/SLTA dan mahasiswa mengikuti seleksi kompetisi Pekan Olahraga Pelajar Nasional (Popnas), dan Pekan Olahraga Mahasiswa (Pomnas). Hasil pembinaan usia dini, Popnas, dan pembinaan pada klub-klub olahraga diidentifikasi dalam rangka pembinaan dan peningkatan prestasi terhadap cabangcabang pilihan yang cocok dengan potensi daerah dan karakteristik masyarakat setempat. Ada cabang-cabang prioritas untuk dibina dan semua fasilitas untuk atlet ditanggung dan dibiayai pemerintah melalui Kantor Dinas Pemuda dan Olahraga. Dengan disahkannya Rancangan Undang-Undang Olahraga menjadi Undang-Undang Sistem Keolahragaan Nasional diharapkan dapat membawa dampak positif dan pencerahan bagi masa depan olahraga di Indonesia.

Evaluasi program yang dilakukan diharapkan akan menemukan fakta pelaksanaan kebijakan publik di lapangan yang hasilnya bisa positif ataupun negatif. Sebuah evaluasi yang dilakukan secara profesional akan menghasilkan temuan yang objektif yaitu temuan apa adanya baik data, analisis maupun kesimpulannya tidak dimanipulasi yang akhirnya akan memberi manfaat kepada perumus kebijakan, pembuat kebijakan dan masyarakat.

Endang M (2011:121) menyatakan CIPP merupakan singkatan dari Context, Input, Process and Product. Model CIPP bertujuan untuk membantu evaluator dalam mengevaluasi program, projek, atau institusi. Hal inilah yang menjadi dasar pemilihan model yang akan dipakai oleh peneliti karena sistem pembinaan adalah suatu bentuk program. Jadi model CIPP cocok dipakai untuk mengevaluasi sistem pembinaan. Model evaluasi CIPP dilakukan secara komperhensif untuk memahami aktifitas-aktifitas program mulai dari munculnya ide program sampai pada hasil yang dicapai setelah program dilaksanakan.

\section{METODE PENELITIAN}

Penelitian ini termasuk ke dalam jenis penelitian kualitatif. Pendekatan kualitatif yang digunakan dalam penelitian evaluasi program ini adalah CIPP Model (Stufflebeam 
2003) ditinjau dari tahapan- tahapan context, input, prosess dan product. Artinya untuk memperoleh informasi yang akurat dan objektif serta membandingkan apa yang telah dicapai dari program pembinaan olahraga bola voli di Pengprov PBVSI Sumatera Selatan, dengan standar yang telah di tetapkan.

\section{a. Populasi dan Sampel}

Sampel penelitian ini adalah tim bola voli puteri Sumatera Selatan. Alasan peneliti mengambil Sumatera Selatan sebagai sampel adalah : 1) Sumatera Selatan pernah mencatatkan prestasi di ajang pekan olahraga nasional, tetapi sekarang prestasi itu sulit sekali dicapai 2) Belum sanggupnya Pengprov Sumatera Selatan menghasilkan atlet yang berkualitas.

\section{b. Desain dan Prosedur}

\section{a) Pengumpulan Data}

Pengumpulan data ialah mencari, mencatat, dan mengumpulkan semua data secara obyektif dan apa adanya sesuai dengan hasil observasi dan wawancara di lapangan yaitu pencatatan data yang diperlukan terhadap berbagai jenis data dan berbagai bentuk data yang ada di lapangan yang diturunkan peneliti serta melakukan pencatatan di lapangan.

b) Reduksi Data

Data yang telah terkumpul dipilih dan dikelompokan berdasarkan data yang mirip atau sama. Kemudian data ini diorganisasikan untuk mendapatkan kesimpulan data sebagai bahan penyajian data. Penyusunan data dilakukan dengan pertimbangan penyusunan data sebagai berikut :

(1) Hanya merumuskan data yang penting dan benar-benar dibutuhkan,

(2) Hanya memasukan data yang benar-benar obyektif,

(3) Hanya memasukan data yang autentik,

(4) Membedakan antara data informasi dengan pesan pribadi responden.

c) Penyajian Data

Setelah diorganisasikan, selanjutnya data disajikan dalam uraian-uraian naratif disertai dengan bagan atau tabel untuk memperjelas penyajian data.

d) Penarikan Kesimpulan Atau Verifikasi

Setelah data disajikan, maka dilakukan penarikan kesimpulan atau verifikasi. Untuk lebih jelasnya proses pengumpulan data, reduksi data, penyajian data, dan penarikan kesimpulan atau verifikasi, serta interaksi dari ketiga komponen dapat dilihat pada gambar sebagai berikut :

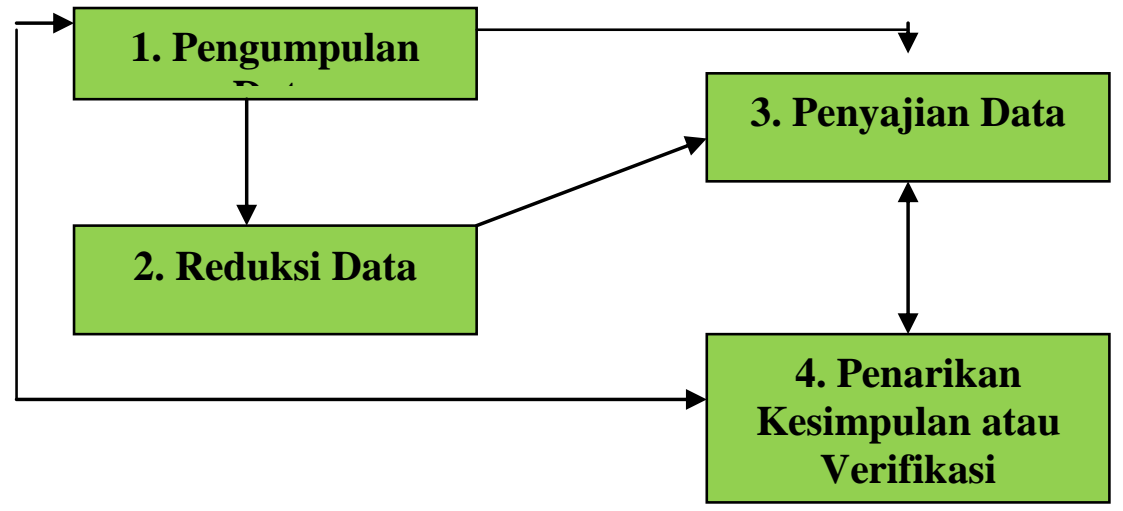

Gambar. Desain Penelitian 


\section{c. Instrumen}

Sumber data, baik data primer maupun data sekunder yang digunakan dalam penelitian ini diperoleh dari pengurus provinsi PBVSI yang meliputi :

1. Paper : dokumen tentang tim bola voliputri SUMSEL, dokumen atlet, dokumen pelatih, majalah, buku-buku dan lainnya.

2. Place : tempat latihan, sarana dan prasarana, asrama, kegiatan latihan.

3. Person : pengurus, pelatih, atlet, masyarakat, dan tenaga penunjang.

\section{HASIL PENELITIAN}

Analisis data dapat dilakukan melalui kegiatan penyusunan dan penafsiran untuk menyusun kesimpulan. Karena keterkaitan dengan fenomena untuk dimaknai sesuai dengan latar alamiah, maka harus dipenuhi analisis data kualitatif, yaitu: naturalistik, analisis induksi dan holistik. Naturalistik, yakni analisisi data harus berdasarkan situasi nyata yang berubah secara alamiah, terbuka dan tidak ada rekayasa pengontrolan variabel. Analisis Induksi, yakni dengan mendasar prosedur berfikir induksi, mengungkapkan data khusus, detil, untuk menemukan kategori, dimensi, hubungan penting dan asli, yang diungkapkan dalam pertanyaan terbuka. Holistik, artinya totalitas fenomena harus dipahami oleh peneliti sebagai suatu sistem yang kompleks, keterkaitan menyeluruh dan tidak dilihat secara parsipal (Samsudi, 2006 : 102).

\section{Evaluasi Context}

\section{a) Sistem pembinaan Atlet Tim PON Bola Voli Puteri Sumatera Selatan}

Wawancara dengan Sekum PBVSI Sum-Sel Bapak H. Faisol Dulhai sebagai berikut:

“............Tim Voli Putri Sumsel saat ini mulai di bina sejak dini. Program ini kian digalakkan secara inisiatif dengan membentuk klub-klub di masingmasing daerah yang ada di Sumatera Selatan guna mengembangkan sumber daya atlet yang ada. Program pembinaan yang selama ini diterapkan belum mencapai hasil yang maksimal.... “(15 April 2013)

\section{b) Ketersediaan Sarana dan Prasarana}

Berdasarkan data yang ada ketersediaan sarana prasarana di Sumatera Selatan masih sangat minim. Hal ini dibuktikan dengan terbatasnya kebijakan pemerintah dalam penggunaan hall di komplek kampus Bumi Sriwijaya.

\section{c) Dukungan Pemerintah}

Berdasarkan hasil temuan di lapangan, dukungan pemerintah dan masyarakat di Sumatera Selatan dapat dikatakan masih sangat minim. Dalam rapat koordinasi yang diikuti utusan KONI dan pengurus cabang olahraga se-Sumsel (Kamis, 29 November 2012), KONI Sum-Sel tetap memprioritaskan pembinaan cabang olahraga perorangan. Sebab cabang perorangan dianggap berpeluang mendapat medali pada Pekan Olahraga Nasional (PON).

\section{d) Ketersediaan Sumber Daya Manusia}

Sumber Daya Manusia yang ada di Sumatera Selatan, tidak kalah bagus dengan provinsi-provinsi lainnya yang ada di Indonesia. Hanya sistem pembinaan yang belum maksimal menyebabkan Sumatera Selatan belum mendapatkan prestasi yang memuaskan. 


\section{Evaluasi Input}

a) Rekruitmen Pelatih dan Asisten Pelatih

Penerimaan pelatih dan asisten pelatih tim PON bola voli puteri Sumatera Selatan terdapat beberapa syarat yang ditentukan oleh pengurus PBVSI Sumatera Selatan yaitu : (1) memiliki lisensi kepelatihan, (2) memiliki pengalaman, baik sebagai pelatih maupun pemain, (3) mampu merancang program latihan, dan (4) mampu bekerja keras dan mampu menutupi kekurangan masalah yang ada.

b) Rekruitmen Atlet

Mengenai penerimaan atlet yang memperkuat tim PON bola voli puteri Sumatera Selatan, sistem yang dilakukan adalah (1) melakukan penyeleksian berawal dari ajang Pekan Olahraga Kota kemudian berlanjut penyeleksian di ajang Pekan Olahraga Provinsi. Selanjutnya Kabupaten atau Kota yang mendapatkan posisi 1,2 dan 3 pada ajang Porprov, berhak mewakili Sumatera Selatan dalam Ajang PraPON. (2) Selain itu kriteria postur tubuh serta Skill yang dimiliki atlet berpengaruh juga pada lolos atau tidaknya atlet tersebut dalam penyeleksian.

c) Kelayakan Sarana dan Prasarana

Dalam penelitian ini menunjukkan bahwa untuk kesuluruhan sarana dan prasarana dalam keadaan yang minim, masih belum layak dan belum lengkap serta belum memadai. Masih banyak kekurangan yang dijumpai, seperti tidak ada pemondokan (asrama), tidak ada transportasi, bola yang diguakan masih sedikit, masih menggunakan lapangan outdoor dan sebagainya.

d) Dana

Dana untuk pembinaan tim bola voli puteri Sumatera Selatan masih sangat minim karena belum ada dana khusus Anggaran Dasar Rumah Tangga (AD/RT) untuk pembinaan olahraga. Dana untuk pembinaan tim bola voli puteri Sumatera Selatan berasal dari dari bantuan KONI dan pihak ketiga (Bank SumSel BaBel) itu pun hanya untuk keperluan mengikuti kejuaran Pekan Olahraga Nasional. Untuk pada masa TC, tim tidak memperoleh bantuan dana sama sekali.

\section{Evaluasi Process}

a) Pelaksanaan Program Latihan

Program latihan yang dilaksanakan secara keseluruhan telah berjalan dengan baik. Dalam pelaksanaannya sudah ada pemberian kontrol pada pelaksanan program latihan. Pelatih juga tidak hanya memberikan latihan fisik. Tetapi juga memberikan latihan taktik baik menyerang atau pun bertahan. Demi tercapainya keberhasilan tim juga melakukan kegiatan latih tanding dengan klub-klub yang berada di Kota Palembang.

b) Konsumsi

Tidak ada dana konsumsi untuk TC. Atlet hanya mendapatkan air mineral, dimana untuk membeli air mineral tersebut Kepala Pelatih mengeluarkan dana pribadi. Jangankan untuk membeli buah-buahan untuk asupan tenaga atlet, air mineral pun tidak dibantu oleh pemerintah setempat dikarenakan dana yang minim.

c) Kesejahteraan

Berdasarkan hasil wawancara selama peneliti melakukan penelitian mengenai evaluasi terhadap aspek kesejahteraan di tim bola voli puteri Sumatera Selatan didapatkan hasil sebagai berikut : (1) aspek keuangan, tidak ada kesenjangan uang saku antara pelatih dan atlet sehingga terkesan pelatih sama dengan atlet atau pemain, (2) selama melakukan TC pelatih dan atlet tidak mendapatkan pelayanan asrama. 
d) Transportasi

Mengenai evaluasi terhadap aspek transportasi di tim bola voli puteri Sumatera Selatan didapatkan hasil yaitu : pemerintah Sumatera Selatan tidak menyediakan sarana transportasi untuk menunjang program pembinaan atlet puteri bola voli di Sumatera Selatan.

e) Koordinasi

Aspek ini meliputi koordinasi antara pengurus, pemerintah, atlet, pelatih, dan orang tua. Berdasarkan hasil wawancara selama peneliti melakukan penelitian, didapatkan hasil bahwa tidak ada koordinasi yang baik antara pemerintah, atlet, pelatih dan orang tua. Koordinasi hanya terjalin antara pelatih dan atlet itupun dikarenakan pelatih dan atlet selalu bertemu dilapangan. Selebihnya tidak ada koordinasi yang terjalin.

\section{Evaluasi Product}

a) Prestasi

Sumatera Selatan hanya mampu menempati empat besar di ajang Pekan Olahraga Nasional (PON) pada tahun 2004. Selebihnya Sumatera Selatan hanya mampu lolos dari kualifikasi Porwil (Pra-PON). Namun dikarenakan perubahan sistem dari Porwil menjadi Kejurnas Nasional, membuat peluang lolos Sumatera Selatan menjadi kecil terutama 2 PON terakhir (2008 dan 2012).

\section{PEMBAHASAN PENELITIAN}

\section{Evaluasi Context}

a) Sistem Pembinaan Tim Bola Voli Puteri Sumatera Selatan

Di Sumatera Selatan sistem pembinaan atlet bola voli masih sangat jauh dari harapan. Tidak ada keseriusan dalam membangun tim yang solid dan sistem yang ada terkesan asal jalan. Pembinaan usia dini pun dirasakan sangat kurang sehingga tidak berkembangnya atlet yang berkualitas khususnya pada cabang olahraga bola voli. Kompetisi yang minim juga sangat berdampak pada ketidakmasimalnya pembinaan atlet voli di Sumatera Selatan.

b) Ketersediaan Sarana dan Prasarana

Sumatera Selatan memiliki sarana prasarana yang bertaraf internasional, sayangnya fasilitas tersebut dikelola oleh pihak swasta sehingga untuk menikmati fasilitas tersebut dikenakan biaya sewa yang harus dibayarkan kepada pihak pengelola. Fasilitas tersebut akan kembali kepada pihak provinsi setelah 25 tahun ke depan.

c) Dukungan Pemerintah dan Masyarakat

KONI SumSel lebih memprioritaskan cabang olahraga individu dibandingkan cabang olahraga beregu. Semestinya hal tersebut tidak boleh terjadi karena baik cabang olahraga individu dan cabang olahraga beregu merupakan satu kesatuan yang harus dibina sepenuhnya. Jika hal tersebut masih tetap berlangsung, maka dikhawatirkan cabang olahraga beregu lama kelamaan akan berkurang minatnya.

\section{Evaluasi Input}

a) Rekruitmen Pelatih dan Asisten Pelatih

Penerimaan pelatih dan asisten pelatih tim bola voli puteri Sumatera Selatan dilakukan dengan cara menunjuk langsung pelatih dari klub yang mendapatkan juara pertama dan kedua pada ajang Porprov. Beberapa persyaratan yang ditetapkan PBVSI Sumatera Selatan untuk menjadi pelatih, yaitu : (1) memiliki 
lisensi kepelatihan, (2) memiliki pengalaman, baik sebagai pelatih maupun pemain, (3) mampu merancang dan memiliki program latihan.

b) Rekruitmen Atlet

Seleksi penerimaan atlet tim bola voli puteri Sumatera Selatan belum maksimal dimana tim yang terbentuk belum mewakili ke-14 Kabupaten yang ada di Sumatera Selatan. Semestinya pemerintah daerah setempat menyaring bakal calon atlet per kabupaten yang ada. Seleksi atlet yang dilakukan dapat dilaksanakan dengan cara membuat tim talent scotting dan melakukan kejuaraan-kejuaraan tingkat kabupaten.

c) Kelayakan Sarana dan Prasarana

Sarana prasarana yang dimiliki oleh pemerintah provinsi Sumatera Selatan khususnya pada cabang olahraga bola voli tidak ada. Terdapat gedung/hall di Sumatera Selatan, namun gedung tersebut masih dikelola oleh pihak swasta dan akan kembali ke pemerintah setempat setelah 25 tahun ke depan. Tim bola voli puteri Sumatera Selatan yang telah tebentuk untuk mengikuti ajang pra-PON kemarin melakukan pemusatan latihan di salah satu sekolah olahraga yang berada di kota Palembang.

d) Dana

Pembiayaan pelaksanaan program pembinaan pada tim bola voli puteri Sumatera Selatan sampai saat ini belum mencukupi jumlah kebutuhan yang sebenarnya untuk pembiayaan proses pembinaan. Sumber dana yang dipakai untuk pembiayaan program pembinaan tersebut menggunakan anggaran rutin dari KONI Sumatera Selatan dan pihak ketiga.

\section{Evaluasi Process}

a) Program Latihan

Program latihan yang dilaksanakan di tim bola voli puteri Sumatera Selatan secara umum telah berjalan dengan baik. Dalam pelaksanaannya sudah ada evaluasi dan kontrol pelaksanaan program latihan. Untuk mendukung keberhasilan atletnya dilaksanakan kegiatan latih tanding dengan klub-klub yang ada di bawah naungan PBVSI Sumatera Selatan atau dengan klub-klub di luar daerah.Kesejahteraan

b) Konsumsi

Pemberian konsumsi bagi atlet tim bola voli puteri Sumatera Selatan, tidak sesuai dengan teori keolahragaan mengenai asupan makanan yang harus diberikan bagi atlet/olahragawan dikarenakan tidak terlaksana dengan baik dan bijak.

c) Koordinasi

Hanya pelatih, atlet dan orang tua yang sering melakukan koordinasi. Selebihnya tidak ada koordinasi yang terjalin. Di lapangan koordinasi pelatih dan atlet terlaksana dengan baik, hal ini dapat dilihat keharmonisan yang terjadi di sela-sela latihan. Sedangkan di luar lapangan, koordinasi hanya terjadi antara pelatih dan orang tua dimana pelatih sering memberikan masukan kepada orang tua tentang kinerja para atlet begitu pun sebaliknya.

d) Kesejahteraan

PBVSI Sumatera Selatan memberikan kesejahteraan yang layak bagi pengurus, pelatih dan atlet. Pertama dari aspek keuangan, contohnya gaji pengurus, pelatih dan atlet sudah cukup menunjang kesejahteraan. Selain itu juga diberikannya bonus bagi atlet, pelatih dan pengurus bila mengahasilkan prestasi. Kedua dari aspek perlengkapan, atlet diberikan sepatu, kostum, jaket, dan training. 


\section{e) Transportasi}

Transportasi yang menjadi media dalam kelancaran proses pembinaan justru terlihat kurang diperhatikan oleh pemerintah Sumatera Selatan karena pemerintah setempat tidak menyediakannya. Atlet dan pelatih menggunakan kendaraan pribadi mereka masing-masing untuk menuju tempat latihan.

\section{Evaluasi Product}

a) Prestasi

Secara umum bahwa prestasi yang dicapai oleh Sumatera Selatan khususnya 2 PON terakhir di Kaltim (2008) dan Riau (2012) belum memenuhi target yang ditentukan dari PBVSI Sumatera Selatan, dimana menajemen menargetkan Sumatera Selatan lolos dalam kualifikasi PON atau delapan besar.

\section{KESIMPULAN}

Berdasarkan pembahasan mengenai program pembinaan tim PON bola voli puteri Sumatera Selatan dapat disimpulkan sebagai berikut :

a) Pelaksanaan pembinaan tim PON bola voli Puteri Sumatera Selatan masih terkesan asal jalan. Sarana dan prasarana belum memadai, dukungan pemerintah juga belum terasa sepunuhnya. Hanya saja sumber daya manusia yang dimiliki Sumatera Selatan sudah bisa bersaing ditingkat nasional.

b) Input pembinaan tim PON bola voli puteri Sumatera Selatan masih banyak kekurangan untuk mencapai sebuah prestasi yaitu masih terjadinya pembinaan yang instan, tim yang terbentuk belum sepenuhnya mewakili ke-14 kabupaten yang ada di Sumatera Selatan serta dana yang minim.

c) Process pembinaan tim PON bola voli puteri Sumatera Selatan yang terdiri dari aspek pelaksanaan program latihan, konsumsi, koordinasi, kesejahteraan, serta transportasi yang terkait belum terlaksana dengan maksimal oleh pengurus berdasarkan data dan fakta secara nyata di lapangan.

d) Product pembinaan tim PON bola voli puteri Sumatera Selatan belum mencapai prestasi puncak. Bahkan pada PON 2008 dan 2012 tim PON bola voli puteri Sumatera Selatan tidak lolos pada kualifikasi Pra-PON.

\section{DAFTAR PUSTAKA}

Dirjen Olahraga Depdiknas. (2004). Pedoman Mekanisme Koordinasi Pembinaan Olahraga Kesegaran Jasmani dan Kelembagaan Olahraga. Jakarta.

Harsono, (2000). Perencanaan Program Latihan. Bandung PT Remaja Rosdakarya. http://artikel-olahraga.blogspot.com, 2008.

Mulyatiningsih, Endang. (2011). Metode Penelitian Terapan Bidang Pendidikan, Bandung : Alfabeta. 
Samsudi. (2006). Disain Penelitian Pendidikan. Semarang: Universitas Negeri Semarang Press. Depdikbud.

Stufflebeam, D.L. (2003). The CIPP Model Evaluation. Presented at the 2003 Annual Conference of the Oregon Program Evaluators Netrwork (OPEN). 